\title{
The Power of Subaltern Memory in Mahasweta Devi's Bedanabala. Her Life Her Times
}

\author{
Quleen Kaur Bijral \& Vandana Sharma \\ Department of Languages and Literature, Shri Mata Vaishno Devi University, Katra, JEKK. \\ Email:quleen.kaur@gmail.com
}

\begin{abstract}
The novel "Bedanabala. Her Life. Her Times" is an uncompromising narrative of Indian society which despite being ridden with tales of oppression, is but strategically eclipsing these tales in the chapters of official epistemologies. The paper vis-a-vis this novel aims to address the representation of a subaltern as an outcast in the backdrop of India's Independence movement, rise of nationalistic or elitist patriotism, and strides of modernism which but do not surface in the underbelly of India's oppressive customs of social discrimination. The paper also aims to address the subversive significance of Orality as in the subaltern memories which in the novel are recollected by Bedanabala to attack the universalised, provincial and exclusive confines of Indian historiography. Why the pages of elite history ignore the voice of the subaltern? How this annihilation of subaltern story is detrimental to the making of subaltern identity? Finally, how to ensure these undocumented stories are invoked to author subaltern histories and thereby reinstate subaltern as a maker than an outcast of society and its history.
\end{abstract}

Keywords: Sublatern Memory, history, Orality, Mahasweta Devi

The story of an outcast- an outcast who is shunned from the world while still exploited by the same, is how the novel Bedanabala. Her Life Her Times (2005) has been narrated by Mahasweta Devi. It encompasses the subaltern memories of a woman, Bedanabala, whose mother was liberated from a house of ill-repute and in these recollections Mahasweta Devi has radically attacked official histories which do not incorporate these historically significant tales of human exploitation. The paper examines Mahasweta Devi's novel as a testimony of subaltern memory or Orality in that it is a subversive tool of rectification which firstly revisits the scandalous misrepresentation of the subaltern; secondly acts as a corroborating and counter-hegemonic evidence to apprehend and correct the falsification of this representation; and thirdly inaugurates the making of subaltern account thereby empowering the subaltern to articulate his/her identity. In the light of these arguments, the objective of the novel can be ascertained as:

(to) construct a history not often documented. A history that runs parallel to the official narrative of India's modernism and nationalism: that of woman outcast because they are fallen.... (Who are under duress) entertaining men, developing liaisons, intertwining their dreams and passions with the destiny of a country struggling for independence and questioning oppressive time-worn social customs. (Devi 2005, p. 1)

While raising these issues of the deliberate ignorance in Indian historiography, the novel apprises the readers with the ramifications of being ostracised as an outcast, and puts forth questions as -

(c) AesthetixMS 2016. This Open Access article is published under a Creative Commons Attribution Non-Commercial 4.0 International License (http://creativecommons.org/licenses/by-nc/4.o/), which permits non-commercial re-use, distribution, and reproduction in any medium, provided the original work is properly cited. For citation use the DOI. For commercial re-use, please contact aesthetixms@gmail.com. 
how this tradition of out casting continues unchecked to date and why and when the outcast yearns to be accepted, and how he is but exploited to only further his subalternity; secondly if his history is at all written, then why is it downright scandalous as he is represented as an immoral weed of the society and not as a human; thirdly why is the subaltern recurrently stigmatised as a source of sin, and malady; lastly, if at all there are changes with time, why the modernizing proposals and projects hardly reach the fringes, the margins, and the cesspools where the outcast as an subaltern is imprisoned. These compelling questions are posed by the narrator of the novel, Bedanabala, who recollects the tale of her mother and consequently highlights the grim reality of being a prostitute and the treatment meted out to them by the society. In this powerful reminiscing or recollection, Bedanabala through her subaltern memory not only speaks of the past, but also connects it with the present to expose the continuing misrepresentation of the prostitutes as source of evil, which acquits the male customers and the elite for that matter of any role in dehumanizing the women.

The novel Bedanabala. Her Life Her Times is a recollection of the past. The eponymous protagonist of the novel Bedanabala recollects the past of her mother, and in her endeavor to remember it one can notice how she intends to expose the strategic erasure of the elitist crimes against a subaltern class. Bedanabala's memory serves as an individual memory and being a tool of oral tradition, it narrates to us one of the grim chapters of Indian history which is but never written. The women in the novel are victims of elitist authority, and Bedanabala while reinforcing and resurrecting her memory traces episode after episode to substantiate the need for a subaltern history. The novel as such is reinforcing the memory of the past through recollection and a proof that once the memory is strengthened, it empowers the subaltern to oppose the totalitarian system which had intentionally obscured the reality of the past. To add more, it has been a historic technique of the Mahasweta Devi, as evidenced in the novel, whereby she employs "empirical research into oral history of the cultures and memories of tribal communities (which is deemed to be) the first of its kind in India" (Chatterjee 2004, p. 118). In underscoring these analyses the paper aims at highlighting how:

Non-elite victims and witnesses frequently struggle to preserve and validate their own memories under the weight of state and elite impositions...active memory- work as a survival strategy in appalling circumstances...(can be called as) subaltern memories. (Gray 2004, p.13)

The key points to be noted in this assessment are the preservation of subaltern memories, attacking elite impositions, and how memory serves as a survival strategy. In regard to the elitist imposition on subaltern memory, Mahasweta Devi through the main protagonist Bedanabala and her powerful reminiscences has exposed the victimization of the women, and how with time they become cognizant of their exploitation and make an effort to bring a change. Accordingly, the paper proposes to discuss - If history is manufactured to tell lies, then how does subaltern memory subvert these spurious accounts, in order to furnish a subaltern history? Consequently, the paper establishes that though the sources of official production and transmission of history can be tampered with, a genuine account of history can be established by applying the corroborative tool of subaltern memory. Memory does not destabilize the order in the society but exposes the concocted lies that shockingly sanction the authority to perform its dominance in the absence of checks and balances. Subaltern Memory, hence, arrests the authority by: firstly exposing the truth of the past, hence ensuring that the elite is indicted and deterred to repeat its follies; secondly in mapping individual memories which are a source of identity for the subaltern; and thirdly revisiting the collective memory propagated by the elite to extract the truth and 
establish it vis-a-vis individual memories. It certainly begs the question - why the mainstream forgets or is hell-bent to erase these memories? The answer is no one is listening to the subaltern, no one cares about the past, and hardly anyone realizes the significance of memory that connects the past with present. At this point, it is pertinent to note Mahasweta Devi's emphasis on memory as a source of history-writing where it can be ascertained that memory as evidenced in the novel informs the present with the errors of the past. Devi states:

Memory is so crucial, past is so crucial. Tell me, what is our present other than a continuation and product of the past. Similarly, our future is born out of our present. So, in order to understand our present and visualize our future we have to go back to our past with the help of memory. (Outlook India, 2001)

While observing this statement by Devi, the significance of memory is justified especially in view of her work Bedanabala. Her Life Her Times. Memory while exposing the past ensures that the present is cognizant of it to create a progressive future. The paper, accordingly, has further investigated how the novel approaches the subject of memory as a debate between collective memory and individual memory. Collective memory, as ascertained in the novel, is what the mainstream as a whole thinks about the prostitutes - "damned women" while individual memory as evidenced in the voice of Bedanabala shows how the character subverts these scandalous strains of collective memory. The collective memory of the society considers prostitutes as symbols of impiety and brands these women as sins. It, therefore, misrepresents the women as culprits hence guaranteeing that they remain lodged in the recesses of society as oppressed. Further, those who struggle to break these calumnious and painful fetters are but unsuccessful, because of the sheer rigidity of the system that refuses to see them as victims. Known in the society as "rotten to the core", hence how a subaltern can be uplifted when even the society sees them as a social malaise, a scourge of sin, and other scandalous epithets and names. These misrepresentations are embedded in the collective memory due to which even if times change the memory resurfaces to recurrently stamp these women as perpetrators of immorality. For this reason, the subaltern who is once made an outcast, unless his/her story is recognised by the mainstream, and a radical step is taken to sensitize the masses, there can be no recourse for them. It is due to this collective memory, the women who wish to return to the society and yearn to be respected by it are but abused as an outcast.

Consequently, Devi has incorporated the collective memory of the society and has made it to stand the test of individual memory. As stated earlier, the collective memory is the official version of truth which is deprived of authenticity and is blinkered through and through, whereas individual history is a personal account of the past which is borne by the victim or the subaltern. In the novel the aspect of collective memory has been depicted by the elitist authority whereas the subaltern or individual memory has been reflected in the character of Bedanabala. The objective being, that subaltern memory or oral accounts can subvert the abuse of power of the elite and engender a subaltern history without any interference of the elite. In examining the novel from this perspective, it has been observed that Devi has attempted to subvert the elitist authority and expose it to render a subaltern record. Further, it has been analyzed how the author has investigated the relation of subaltern memories with power: can it subvert authority? Accordingly, in the novel it has been examined how:

The question of memory's relation to power lurks within the battle between official and subaltern memories... Looking at the big structures of history and how they are experienced on the local levels reveals (how) subaltern memories...rise through the cracks and become counter-hegemonic. (Gray 2004, p.76) 
While examining these discourses on subaltern memories, it can be said that subaltern memory does not only apprehend the official history but also attacks the official memory that is imposed on the community at large as the only legitimate or legal one. In view of this, the two conflicting memories hence are in a continuous process to negate each other as has been witnessed in the novel. The society as an emblem of elitist authority continually attempts to thrust the truth about the prostitutes in the bins of amnesia so that they get a full lease to exploit them as society would not see them as victims. This is where Bedanabala struggles to retrace her memory, preserve it and employs it to oppose the official memory and hence the novel proves that there is always a game of subversions and domination between official and subaltern memory. Bedanabala's recollection of her mother and other prostitutes can thus be witnessed as a counter-hegemonic journey taken by the character to re-enforce the subaltern memory in the face of the official denial and attrition of truth. Knowing this ignoble state of affairs, Mahasweta Devi has attempted to attack the system, and its corrupt making of history which intentionally marginalises the subaltern in print, so that it's Orality is not able to expose the malevolent elements of authority that runs this system.

Further, it can be claimed as discussed above, that collective memory tends to overlook the subaltern memory as it gives precedence to a universalized, homogenous and limited model of history or memory. That is, one model for all. In doing so, it shockingly eliminates, relegates or bypasses the histories or memories of the subalterns. Many proposals are tabled by the elite to set up a collective memory for the society as a whole or a homogenized model which speaks for everyone. This model can have two manifestations - either it incorporates both the elite and the subaltern or undermines one over the other. While examining the strains of collective memory and its proposed agenda, it can be stated:

A single, common memory and a shared history offers lessons for the present and the future... (But) if we do not work toward creating a personal and communal version of the past, there will remain only one memory that might cover up other different memories....The struggle of people against power is the struggle of memory against being forgotten. (Loh 2013)

In the light of this argument, the society at large might consider it progressive to foster a collective memory and produce a collective history, but as can be witnessed in the novel, it smothers the different memories hence relegating the subalterns as non-existent victims and even criminals who are not worthy to be considered a part of a country's history. To add more, in doing so, these subalternized communities are always in the danger of being eliminated lest their memory becomes public and challenges the superficial, propagandist, and provincial accounts of the official memory and history. Hence, the endeavor of Bedanabala in the novel is to remember the past lest it is forgotten or suppressed by the imposition of a collective memory that has misrepresented and scandalized prostitutes as evil-doers. After all, if the subaltern memory is sabotaged, what can be its ramifications? The novel pointedly exposes the aftermath to emphasize on the need to articulate and preserve subaltern memory; otherwise official history would continue to impose on the subaltern the falsities hence ensuring further violations are carried out without any backlash.

Orality or subaltern memory, as evidenced in the novel, is a tool of protest which a subaltern wields to rectify his misrepresentation in the society. In the Indian context, one can draw a comparison between story and history to show how Orality has been a source of power for the subaltern. In saying this the argument is not to create a rift between the story or history or show one superior or inferior to the other, but to find out how story works as an instrument of 
power for the subaltern. History has been a weapon of the elite to justify and perpetuate its dominance, in the midst of this, how stories allowed the subaltern to retain its identity. In the Indian context, it can be examined how story (Katha) became an instrument by which the subaltern could subvert the official narratives or (Itihas) and find a niche of his own. It can be stated:

'Itihas' (is) an Indian way to know the past...stands for the story of a dominant tradition. On the other hand, the term 'story', liberates even marginalized groups of Indian society and enables them to enter the meaningful domain of knowing, inventing, creating and telling the past as a constant dialogue with the present. (Sen 2010, p.43)

Noting this profound exemplification of story and history, Mahasweta Devi's work can therefore be examined as employing story or oral records as a tool of history writing to rectify the dominant tradition, and consequently liberate the subjugated classes of Indian society. Here story is not fiction; it is a symbolic representative of the living ethos of a subaltern community and a powerful medium to assert it. In this intervention, reinterpretation, subversion of history by means of story or Orality, the dehumanized groups of India are empowered to speak and can be listened to in the mainstream. Mahasweta has also claimed that this form of history writing is a "very valuable source of history" and has further attested to the empowering attributes of such technique of history writing by stating, "I have always tried to explore people's version of history . .. I felt that history comes alive authentically through the oral tradition” (Singh 2014, p.24).

At this juncture, it can be asked what model of history is envisaged while employing subaltern memory? If the objective of the novel, as discussed earlier, is to include that history which "runs parallel to the official narrative of India", and which is but deliberately erased, then the model of history should be inclusive. The need of incorporating oral sources is to ensure the voice of the subaltern that is registered in orality such as subaltern memory is included in the official history. Orality as a means of protest not only empowers the subaltern but also ensures the identity, consciousness and the authentic voice of the subaltern is recorded in the history. While drawing the link between orality and history, critics like Benoy Sarkar have claimed, "Primitives were ignored by history, at its own peril...for history is incomplete and quite unable to guess the future of mankind... He further espoused [that] national unity was possible only through the study of - folk culture" (Mayaram 2005, p.293).

As stated by Sarkar, primitives imply the aboriginals, the non-Aryans, and other marginalised communities whose history is preserved in the folk culture as in myths, legends, songs and other media of Orality. When these sources are included within the history of the nation, it is only then the authentic version of history can be created and legitimatised. In doing so, history needs to have an investigation and incorporation of folk culture, memory, oral and written accounts to serve as an encompassing whole. Such a construction of history and such a model of history writing allows for a scrutiny between - popularly fabricated past and professionally constructed histories (Mayaram 2005, p. 3). In this paradigm, the indigenous models of history writing as in Orality is hence given credit which otherwise were obscured by the British and native elitist historians. According to prominent subaltern critics, - Regionalist histories were replaced by official elite history; the erasure of non-western models of historywriting facilitated the erasure of (marginalised communities) (Mayaram 2005, p.234).

Consequently, in the inclusion of subaltern memory of Bedanabala, the official memory is exposed in its fallacious misrepresentation of the subaltern. Here, it is pertinent to emphasize that orality ensures that history follows an encompassing paradigm with reference to the unacknowledged, misrepresented and exploited subalterns. In the paper, it is subaltern history 
which has been investigated which following the model of inclusive history addresses the need for an encompassing history. The subaltern critics have made a bold and formidable endeavor to seize the agency by which the marginalized community could rectify their identity, existence and history. While, tracing, the genesis of subaltern historiography, it can be noted that its first inception was marked by the deliberations of a group of historians of South Asia whose work appeared in 1982 in a series titled Subaltern Studies. Partha Chatterjee, one of the prominent subaltern critic has highlighted the major progenitors of these series: "Amin and Chakrabarty 1996, Arnold and Hardiman 1994, Bhadra et al. 1999, Chatterjee and Jeganathan 2000, Chatterjee and Pandey 1992, Guha 1982-9" (Chatterjee 2013, p. 94). The critic further has noted the original implication of the term 'subaltern' as employed by Gramci who in his rendition of the term subaltern aimed to address the 'history of the subaltern classes'. In its contemporary notion, the subaltern groups are defined as those masses who are relegated to the margins of the hegemonic structure and it can be, hence, noted, "The history of subaltern groups is necessarily fragmented and episodic. There undoubtedly does exist a tendency to (unify the) historical activity of these groups...Subaltern Groups are always subject to the activity of ruling groups, even when they rebel and rise up' only 'permanent' victory breaks their subordination, and that not immediately" (Bahri 2003, p. 172). Here, Gramsci has emphasized on the significance of history which in case of subalterns has been disjointed and lacking an organic unity and how the hijack of history is invariably linked to the subordination of subalterns. This school of thought was appropriated by the scholars of Subaltern Studies to signify the mass of population who are deprived of an agency. Through the prism of these dynamic deliberations, the Subaltern Studies group began to rectify the fabrications of elitist historiography as spearheaded by Ranajit Guha, who edited the first six volumes of Subaltern Studies, and also claimed, "The historiography of Indian nationalism has for a long time been dominated by elitism - colonialist elitism and bourgeois-nationalist elitism' (Budde 2006, p.95). While an endevour was being made to rewrite elitist history, the discourse on subaltern historiography was taken up by two groups - one which was located in the Cambridge, UK while the other were based in Delhi, India. The objective of subaltern historiography as propounded by the two groups was:

...to oppose the two elitisms. The former (group based in UK) argued that Indian nationalism was a bid for power by a handful of Indian elites who used the traditional bonds of caste and communal ties to mobilize the masses against British rule. The latter (group based in India) spoke of how the material conditions of colonial exploitation created the ground for an alliance of the different classes in Indian society and how a nationalist leadership inspired and organized the masses to join the struggle for national freedom. (Budde 2006, p.95)

Ranajit Guha contested these critical viewpoints on subaltern historiography as hinging on an elitist view and asserted that:

...the former representing a colonial elitism and the latter a nationalist elitism. Both assumed that nationalism was wholly a product of elite action. Neither history had any place for the independent political actions of the subaltern classes. (Chatterjee 2013, p.288)

While dissecting these elitist views, historians of Subaltern Studies began to address two fundamental issues vis-a-vis subaltern classes. The first focus was to emphasize on the difference between the political methods of colonial/nationalist elites and those of the subaltern classes, while the second area of concern was autonomy of subaltern consciousness. In establishing these claims, Chatterrjee notes that the conflict was not only towards the declarations of the colonial historians but also nationalist historians as both believed that subaltern consciousness was 
something imported and not an integral, and self-formed aspect of the subaltern. The thrust of these deliberations was to underscore how the subaltern despite being a cardinal part of India's history was but detached from its making and allotted only a meagre space. It is in this early phase of Subaltern Studies, that model of "history from below 'was established and the major impulse of this project shifted from "what is the true from of the subaltern" to "How is the subaltern represented" (Chatterjee 2013, p.295).

While tracing this brief of genesis of subaltern history, the paper has attempted to expose the misrepresentations in the novel and thereby has aimed to create a subaltern history based on the voice of the subaltern. The official narratives or the collective memory if is exposed of its discrepancies, nasty interpolations and misrepresentations, then there is a significant probability of finding the voice of the subaltern. In the novel, the women are doubly oppressed - first owing to their sex and secondly because of their apparent inferior class. In "Can the Subaltern Speak?" Spivak has claimed, "...the subaltern has no history and cannot speak, the subaltern as female is even more deeply in shadow (Spivak 1996, p.287). This 'shadow' has been a ritualised recurrence in the Indian society, meaning that the subaltern women have been subjected to this oppression since ages and when it comes to the prostitutes in the book, the novel states that this tradition of oppression had rather a ritual or rites of passage by which the prostitutes would be formally forced into oppression. Mahasweta Devi highlights how the society had ritualized this tradition of subordination and that it continues even today. In order to emphasise on this tradition, and its ritualistic custom of discrimination, Devi notes how the whores are through an elaborate ritual pushed into the profession. In this ritual the paper examines; firstly the incorrigibility of the system, in that it cannot be challenged; the brainwashing of the subaltern that it cannot rise once it has been made a subaltern; as a ritual carries with itself divine injunctions, the process of exploitation is hence vindicated in the name of god; and finally how this ritual even prepares the subaltern to accept its subalternity as justifiable. Mahasweta Devi writes:

...a whore needs a priest only twice in her life. When she marries into the profession...And once more at the end. When she's dead...(the ritual has been exposed by the author as)

To this blade of iron I now marry you

All trouble and strife I cross out for you

Everybody's woman. Alone no more.

Till now, a girl. From now, a whore.

You have no afterlife, no rebirth. This lifetime is equal to a hundred lives, a hundred births Wait till tomorrow, you'll find out why. (Devi 2005, p. 22)

Explicitly and most stringently, Mahasweta Devi through the memory testament of Bedanabala, hence records the grim reality of Indian society. It is this Orality which Devi has vehemently demanded from the elite to include in the official tracts as only in exposing and recognizing the subalternization of the victims, can any step be taken to correct it. In recording oral narratives, Mahasweta Devi hence apprises the Indian society of its vicious catacombs and sadistic zones where exploitation of the subaltern remains a truth unheard or unchecked. To challenge and rectify this grim reality, the novel accordingly aims to attack the superficialities, hypocrisies and pretensions of the elite which show either apathy or antipathy for the subalternized outcast.

It has been a debatable issue as to who has the authority to speak for the subaltern. For instance, what gives a non-dalit the right to interpret the Orality of the dalits? This concern has 
been contested by many subaltern critics, one such by Gayatri Spivak. She has maintained that, "there is nothing wrong at all in a non-dalit speaking on behalf of the subalterns-since unlike their ontology, which belongs to themselves, their epistemology might often be accessible only to specialist" (Yadav 2008, p.102). Ranajit Guha also emphasizes this point by referring to Bankim Chandra who had endeavoured to write the history of true India. Guha opines:

Who speaks for the Indian people...who has the right to interpret their past?" ...Bankim Chandra Chattopadhyay, (has claimed) Bengal (India) must have her own history. ...Who is to write? You are to write it. I have to write. All of us have to write... (Guha 1997, p. 153)

In the light of these assessments, Mahasweta Devi's role in representing the subaltern can be agreed with. Besides, it is not the question of who speaks for whom, but what is being spoken. That is, is the representation correct or fallacious? Does it attempt to empower the subaltern or further relegate it to the fringes? Does it, to surmise, speak the truth or not? The paper also argues that perhaps histories have been written on the prostitutes, but do they rectify the misrepresentation of these women who are generally projected as vermin, sluts, and other slanders? Consequently, in saying histories of the subaltern have been written, the question - is it the truth that is being written? - a representation or a misrepresentation? Gayatri Spivak when she put forth the powerful question "Can the Subaltern Speak", what did she imply:

Gayatri Spivak's point was never that subaltern did not speak, but that historians, blind to their own representations did not see how their narratives worked to "speak for" rather than "speak to" subaltern speech. (Hunt 1999, p.160)

Hence, in writing or rewriting history which only strengthens these misrepresentations does not imply that the subaltern can speak. The public knows about the prostitutes but they see them, read about them, and hence cultivate their mentality which slanders these women as "sinners"; hence in this knowledge about the subaltern that is based on misrepresentation, it is downright wrong to say the subaltern can speak. In the novel it is reiterated that these women's history is written but this history constantly brands them as sinners, hence what is needed is a history that sees them as humans, as victims, as subalterns so that the mentality which stamps them as 'bundles of sin' is apprehended. The prostitutes since ages have been stamped with many pejoratives which have become so naturalised that the women do not read them as insults. Devi in this regard notes:

Whores, slut, prostitutes, so many names. But they were just that, names. Neither society nor the women had yet perceived them as insults. These names were old...buried in our history...and every age has branded them different...(Devi 2005, p. 37)

Mahasweta Devi in this narration intends to prove that despite the name being changed and more added to the list, the condition of these women since ages has not ameliorated to a substantial extent. Besides, these names which should be treated as insults are but due to their naturalisation by ritualization have become just names. Further, what these names suggest - is that this tradition of subalternity has been a recurring continuity, and despite its past ranging from one age to another, History is still at a loss to record these stories. Has this loss of history also been naturalised as something legal, legitimate and not a blunder at all? Has it not shocked the historians to rectify history writing so that subaltern records are also incorporated? Has the society forgotten them or is deliberately trying to be amnesiac when it comes to these harrowing oral narratives of subordination and suffering? In provoking the readers to ask these questions and shaking the very foundation of Indian historiography, Mahasweta Devi intends to shatter the comfort zone of history writing so it does not blunder as if its errors are also sanctioned by law. 
Keeping with this tenor of subaltern history and how it can be retrieved by the medium of memory, Mahasweta has not only rectified the misrepresented identity of the prostitutes but has shown how memory can serve as a tool of writing subaltern history. Bedanabala makes the mainstream aware of the misrepresentation of the subaltern, by creating an authentic history while employing her subaltern memory. Who is a criminal and who is not? The impetus is to show that if the mainstream is educated in the legitimate history or the subaltern history then the marginalization of the subalterns can be resolved. Memory, hence, as a tool of history serves as a repository of the past and these assertions can be substantiated by noting Jan Vansigna, a Belgian anthropologist who also attested the importance of memory in the making of history. He has claimed:

...the utterances are transitory but the memories are not. No one in oral societies doubts that memories can be faithful repositories which contain the sum total of past experience and explain the how and why of present day conditions...The mind through memory carries culture from generation to generation... (Vansigna 1985, p. xii)

While evaluating these assertions, the question of memory as a tool of history cannot hence be negated. It is memory by which Bedanabala sensitizes the mainstream to see the truth. However, towards the ending of the novel, Mahasweta Devi, questions whether it is enough that Bedanabala has been able to narrate her recollections of past? Should it not be important that she is also heard? Spivak, when she was asked to explain what she implied by - the subaltern cannot speak"e replied, "It means that even when the subaltern makes an effort to the death to speak, she is not able to be heard, and speaking and hearing complete the speech act. That's what it had meant, and anguish marked the spot (Spivak, 1996, p. 292). Consequently, it is not enough that the subaltern can speak but that she is also heard. The novel also exposes this subaltern dilemma, by highlighting how the subaltern might be speaking but that no one is listening when she avers:

Where's the change? Just that they can speak up now? I am a sex worker and this is my profession? Just that much ...(not) enough for their history to be written.(Devi 2005, p. 75)

To add more, if the subaltern has been able to speak, then why the mainstream is at a loss to listen. Is it that the elite cannot comprehend? Interpret? Or simply listen? Mc Leod in raising these points has opined:

Their muteness is created by the fact that even when women uttered words, they were still interpreted through conceptual and methodological procedures which were unable to understand their interventions with accuracy...Hence, the silence of the female as subaltern is the result of a failure of interpretation and not a failure of articulation. (Mc Leod 2000, p. 195)

Therefore, it is as claimed above not "a failure of articulation" but a 'failure of interpretation'. As the narratives of the subaltern are embedded in the society which is clearly ridden with parochial ideologies, it is difficult for the masses to listen to the voice of the subaltern in its unadulterated, uninterrupted and uncontaminated form. What the mainstream hears is first filtered through the provincial mindset, and then is later dyed in the ink of prejudice emanating from false histories, hence the elite is not able to listen to the truth and remains oblivious. To counter this, it is not enough to recover the voice of the subaltern, but also ensure the mainstream heeds the true voice than the altered tracts. These two functions are aptly performed by the model of subaltern history as examined in the novel.

It is also pertinent to note that there is yet another reason why the mainstream is not able to hear the subaltern. Either the words spoken are too painful that the mainstream represses them 
or they are anti-national that the masses have to desert them. In the latter case, if the memories, for instance, are not in alignment with the present ideology, say present government, the masses are forced to remake it else their memory might be and will be seen as anti-nationalist or seditious. Hence, the masses remould the memories, or the voices than listen to them in their true state otherwise if they are seditious, then these oral tracts of the subaltern surely pose a threat. Out of fear of being arrested, detained or banished the mainstream erases these memories or ignores the subaltern so they can fit in the society and escape any accusation of being antinational. In examining these observations, it can be reiterated:

We remake or repress memories of experience ...because they do not easily accord with our present ideology... Our memories are risky and painful if they do not conform with the public norms or versions of the past. (Perks 2015, p.344)

Consequently, the mainstream fails to interpret the voice of the subaltern not only due to its provincial thought-process but also due to the fear of any official backlash. It is, hence, only by a collective effort, an organic approach, and mass awareness that the mainstream can trace these voices and make sense of their past. Bedanabala by historicizing her memory has been able to pave a way for a historical recording of an Indian past as critics observe, "Amidst the remnants of the collective memories of family, church, and nation, the individual forges his identity by historicizing his own memory (Hutton 1993, p. 151). It is in these recording, the subaltern history is established and by listening to these narratives, a first step can be taken to overcome the failure of listening.

Can, then it be said, that subaltern history empowers the subaltern and sensitises the mainstream? In re-examining the discussions of the paper, it can be stated the novel as an embodiment of subaltern history rectifies the misrepresentation of the official narratives, by employing Orality which retrieves and recovers the true subaltern identity. Secondly, it by exposing the gaps and loopholes of official history ensures subaltern history makes the masses aware of the exploitation of the subaltern. Thirdly, in doing so, the subaltern is provided a pedestal to speak and be heard. In light of these aspects, it can be stated that it is indeed the focus of subaltern historiography to seek for social justice that is be it class or gender oppression, the history should provide the subalterns with an agency to articulate their concerns and issues. Dipesh Chakrabarty in The Politics of Culture in the Shadow of Capital (1997) has stated that it is fundamental to situate Subaltern history in the broader context of historiography. That is, it must address the socially committed commandments that form the basis of its task. As he writes, "Writing subaltern history, documenting resistance to oppression and exploitation, must be a larger effort to make the world socially just. To wrench subaltern studies away from the keen sense of social justice that gave rise to project would be to violate the spirit that gives this project its sense of commitment and intellectual energy" (Chakrabarty, 1997, p.35).

The author has diligently addressed this issue by actively pursuing a history which empowers the subalternized outcasts. She has narrated how in the progress of time, the society broke its orthodox hold of draconian rules and began to heed the voice of these women. Mahasweta writes, "Who knew then, that a day would come when the whores would see for the very first time that there were some people after all who would give them respect, who would not greet them with disgust, with scorn? Who knew then that one day the whores would write in their own hand..." (Devi 2005, p. 25). As a subaltern, these women slowly with time have been empowered as the masses are beginning to listen, and acknowledge the debt of Orality in rectifying official narratives. Devi notes this change in the novel wherein the sensitized men and women do not heed the misrepresentation of the official tracts and listen to the subaltern without 
the mediation of provincial ideologies and rituals. The author highlights the progressive steps taken by masses to heed the subaltern as in formulating Missions like the Nabya Hindu Mission which narrate the simplified interpretations of Gita to the outcast who were hitherto restricted to hear them. The Swadeshi volunteers, in the novel are highlighted who build homeopathic centres for the homeless and the poor, and also the followers of Vivekananda who in the light of the "bogus deviations of Hinduism" strive to reform it. (Devi 2005, p.24). In the novel it is shown how the orthodox society criticises these activists for working for the cause of the subaltern which hence shows that it is only by means of decisive and steady steps that the mainstream as a whole can be saved from the poison of discrimination. Devi notes, "Why do these damned women come here?" to which these sensitised men and women, defiant in their goal, simply reply, "Is there any law forbidding that...we too believe that the Lord may be best served through the care of each and every one of His creations" (Devi 2005, p.26-27). The novel also notes the diligent work done by the outcasts for the betterment of the society as a whole. Though they are abandoned by the masses rather dehumanized as objects, the women do not shirk to do their part in the progress of the nation. Devi notes, "They (prostitutes) feed the poor here, give money for the free medical centre... (Substantial funds are contributed by the women from) the famous red-light area of Calcutta (Devi 2005, p. 27).

In the novel, the author further emphasizes the need to change the parochial conception of whores as class of outcasts, so the masses can see them as humans "born with some rights, some hopes, and not just a scar across their fates" (Devi 2005, p.39). She also tinges the novel with hope that as long as there are 'organic intellectuals' who wish to rid the nation of its provincial mentality, the subaltern can be empowered to work with these intellectuals and further the cause of justice and equality. Further in Bedanabala's testimonials and in Devi's recording of them, it is evident that once the masses are aware, sensitized and empathetic of the conditions of the outcasts, the subaltern scan rise above their imposed statures in the society.

Towards the conclusion of the novel, Devi states that it is upto the women to know that they have their right to break away. They had been brainwashed to believe in their subalternity as divined by the heavens, and such a strategic activity allowed their exploitation to run unchecked. Devi exhorts the subaltern to awaken her subaltern consciousness, and manifest it in fighting for her rights. She writes:

...each prostitute, each sex worker, has the right to light, to break free of darkness. They must know this. They must earn this for themselves. (Devi 2005, p.76)

Only in realizing their exploitation, and that they can overcome it, the subaltern woman can beat the oppressive system and aim for freedom. This realization is what is called subaltern consciousness which Partha Chatterjee says evolves, “...out of the experience of subordination out of the struggle...the daily routine of servitude, exploitation, and deprivation" (Chatterjee 2004, p.292). Leaving the novel at this note, Devi's impetus is to empower the women so they realise the onus to free themselves does not squarely lie on the shoulders of the mainstream; they have to realise it for themselves as said Bal Gangadhar Tilak - freedom is my birthright.

In conclusion, it can be stated that Mahasweta Devi's work Bedanabala. Her Life. Her Times is a testimony to the value of subaltern memory or Orality. Bedanabala narrates her subaltern memory in order to subvert the elitist exploitation and misrepresentation of the prostitutes which has since ages sanctioned the culprits to oppress the subaltern. The author while narrating this novel has amply exemplified, the significance of Orality as a source of history which hence should not be negated. The paper has further ascertained that collective memory has eclipsed the voice of the subaltern, and in tracing the subaltern memories, this attrition of truth 
can be subverted to create a subaltern history. The author, consequently, does not only wish to highlight the history of the subaltern but also intends to enforce the importance of Orality as a historical source. The oral narrative as evidenced in the novel shows how Orality serves as an authentication and augmentation of history and hence why it should be deemed as a legitimate source of history. Further, in recovering Orality, it is the voice of the subaltern which is being retrieved. Orality hence makes the subaltern an architect of his history and gives him/her the power to speak his story. In this mode of history telling, the subaltern as evidenced in the novel, hence is an active participant in speaking his history, where in he/she can rectify official records, reclaim his past and narrate a subaltern record.

\section{References}

Bahri, D.(2003) Native Intelligence: Aesthetics, Politics, and Postcolonial Literature. USA: U of Minnesota Press.

Budde, G. and Conrad, S. and Janz, O. (2006) Transnationale Geschichte: Themen, Tendenzen und Theorien. Germany: Vandenhoeck \& Ruprecht.

Chatterji, S.A. (2004). Women In Black White And Technicolour. New Delhi: Rupa \& Company.

Chatterjee, P.( 2013) Empire and Nation. New York: Columbia University,.

Devy, G.N. (2008). Wealth of Wisdom. The Hindu. $3^{\text {rd }}$ August 2008. http://www.thehindu.com/todayspaper/tp-features/tp-literaryreview/wealth-of-wisdom/article1438164.ece

Devi, M. (1997) The Armeniun Champa Tree. Calcutta: Seagull Books.

Devi, M. (2005) Bedanabala. Her Life. Her Times. Calcutta: Seagull Books.

Devi, M. (2005) Chotti Munda and His Arrow. Calcutta: Seagull Books.

Dasgupta. “The Reaction Has Been So Minimal Among The Urban Educated”. Outlook India, 23 April 2001. http://www.outlookindia.com/website/story/the-reaction-has-been-so-minimal-among-the-urbaneducated/211415

Guha, R. ( 1997) Dominance without Hegemony: History and Power in Colonial India. USA: Harvard University Press.

Gray, P. and Oliver, K. (2004) The Memory of Catastrophe. Manchester: Manchester University Press

Guha, R. (1997) Dominance without Hegemony: History and Power in Colonial India. Harvard University Press.

Hutton, P.H. (1993) History as an Art of Memory. USA: University of Vermont.

Hunt, N.R. (1999) A Colonial Lexicon: Of Birth Ritual, Medicalization, and Mobility in the Congo. Durham: Duke University Press.

India Seminar (2004) The adivasi Mahasweta. Available at: http://www.india seminar.com/2004/540/540\%20ganesh\%2on.\%2odevy.htm (accessed 1 May 2016)

Leod, J. Beginning Postcolonialism. U.K: Manchester UP, 2000.

Loh, K. and Dobbs, S. and Koh, E. (2013) Oral History in Southeast Asia: Memories and Fragments. USA: Palgrave Macmillan US.

Muthukumaraswamy, M.D. (2006) Folklore as Discourse. Channai: National Folklore Support Centre.

Mayaram, S. (2005) Muslims, Dalits, and the Fabrications of History. New Delhi: Orient Blackswan. 
40 | The Power of Subaltern Memory in Mahasweta Devi's Bedanabala. Her Life Her Times

Perks, R. and Thomson, A. (2015) The Oral History Reader. New York: Taylor \& Francis..

Roy, M.N. and Radical Democratic Party (India) and Indian Renaissance Institute (2007) The Radical Humanist. New Delhi: Maniben Kara.

Rowe, L and Llyod, D. (1997). The Politics of Culture in the Shadow of Capital. Durham: Duke University Press.

Sen, N and Yadav, N (2008) Mahasweta Devi: An Anthology of Recent Criticism. New Delhi: Pencraft International.

Singh, H. (2014) The Rani of Jhansi: Gender, History, and Fable in India. Delhi: Cambridge University Press.

Sen, S. (2010) Folklore Tradition. Delhi: Anjali Publications.

Spivak, G. (1996 ) The Spivak Reader: Selected Works of Gayatri Chakravorty Spivak. Ed. Donna Landry and Gerald Mac Lean. New York: Routledge.

Tamand, K and. Yip, T.S. (2010) Gender, Discourse and the Self in Literature: Issues in Mainland China, Taiwan and Hong Kong. Hong Kong: Chinese University Press.

Vansina, J. (1972) Oral Tradition: A Study of Historical Methodology. USA: Transaction Publishers.

-.Oral Tradition as History. James Curry Publishers, 1985.

Quleen Kaur Bijral is a Research Scholar, Department of Languages and Literature, Shri Mata Vaishno Devi University, Katra, J\&K - 182320.

Vandana Sharma Ph.D. is Head, Department of Languages and Literature, Shri Mata Vaishno Devi University, Katra, J\&K - 182320. 